\title{
Molecular alterations of the WWOX gene in nasopharyngeal carcinoma
}

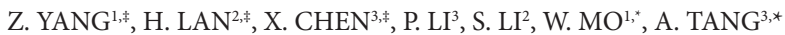

${ }^{1}$ First Affiliated Hospital of Guangxi Medical University, Nanning, People Republic of China; ${ }^{2}$ The People's Hospital Of Guangxi Zhuang Autonomous Region, Nanning, People Republic of China; ${ }^{3}$ Guangxi Medical University, Nanning, People Republic of China.

*Correspondence: mown163@163.com, anzhoutang@126.com

${ }^{*}$ Contributed equally to this work.

Received May 20, 2013 / Accepted July 25, 2013

\begin{abstract}
The WW domain-containing oxidoreductase (WWOX) gene is a candidate tumor suppressor gene. However, its exact mechanism is unclear. This study aimed to investigate the role of the WWOX gene in the development of nasopharyngeal carcinoma (NPC). Tissues were collected from 65 NPC patients. Reverse transcriptase-polymerase chain reaction (RT-PCR) analysis and immunohistochemistry were performed on NPC tissues to determine the expression of WWOX in NPC. The status of WWOX promoter methylation was analyzed by methylation-specific PCR. Moreover, a PCR-based loss of heterozygosity (LOH) assay was conducted to detect the presence of WWOX deletion in NPC. The expression of WWOX in NPC tissues was significantly downregulated compared with that in non-tumorous tissues $(P<0.05)$. The low expression of WWOX was significantly correlated with clinical TNM stage $(P<0.05)$. In addition, methylation of WWOX was detected in $27(87 \%)$ of 31 WWOX protein negative tissues, suggesting that methylation of the WWOX promoter may regulate its expression. We found that a relatively high percentage of LOH was observed in NPC tissues. A significant inverse correlation between WWOX expression and methylation of its promoter was found in NPC tissue ( $\mathrm{rs}=-0.582, P=0.001)$. However, $\mathrm{LOH}$ was not correlated with WWOX expression and methylation of its promoter. Our results show that WWOX gene alteration is an early genetic alteration and may contribute to tumorigenesis of NPC. WWOX may be an important prognostic marker in NPC.
\end{abstract}

Key words: WWOX, nasopharyngeal carcinoma, promoter methylation, $\mathrm{LOH}$

Nasopharyngeal carcinoma (NPC) is a malignant tumor with remarkable geographic and racial distributions, and is derived from epithelial cells. NPC is one of the most commonly diagnosed cancers in South China, Southeast Asia areas, and Latin America [1]. The incidence rate of NPC in South China (e.g., Guangdong, Guangxi, Hainan, Hunan, Jiangxi, Fujian, and other regions; almost $20-50 / 100,000$ people per year) is nearly 25 -fold higher than that in North China and the Western world [2]. Unfortunately, approximately $70 \%$ of patients with the initial diagnosis of NPC present with a locally advanced stage because of the difficulty of discovering it at early stages, and it is highly metastatic and invasive [3]. Therefore, identification of a new biomarker and novel therapeutic target is urgently required for the early detection and effective treatment of NPC.

The WW domain-containing oxidoreductase (WWOX) gene is a candidate tumor suppressor gene. WWOX was first identified in 2000 in a common fragile site FRA16D (locus 16q23.3-24.1) using the shotgun sequencing technique [4].
Previous studies have corroborated the phenomenon that reduced, or absent expression and or aberrant transcripts of WWOX frequently occur in a number of tumors (e.g., breast cancer and non-small cell lung cancer) [5-11]. The restoration of WWOX expression may induce apoptosis and autophagy, and it inhibits tumor growth, suggesting that WWOX functions as a tumor suppressor. Recently, some authors observed a correlation between WWOX expression levels and methylation of its promoter $[12,13]$. Methylation is probably an important mechanism of WWOX gene silencing. Loss of heterozygosity in the WWOX locus has also been reported in many types of cancer [14-17]. Currently, the mechanism is unclear and there is still some controversy regarding the cancer-suppressing gene WWOX [18].

In this study, we measured the expression of WWOX in NPC. We also analyzed the association between WWOX expression and promoter methylation or loss of heterozygosity (LOH) to determine the role of WWOX in NPC and its possible mechanism. 


\section{Patients and methods}

Patients and tissue samples. Tissues from 65 NPC patients and 43 patients with chronically inflamed nasopharyngeal mucosal tissue (as a control) were obtained from the Department of Otolaryngology and Head Surgery, First Affiliated Hospital of Guangxi Medical University, China, from June 2010 to October 2010. The patients all had the initial diagnosis of NPC and did not have radiotherapy and chemotherapy performed. NPC patients included 54 men and 11 women with a mean age of 44 years (range: $30-72$ years). A total of 30 men and 13 women with a mean age of 45 years (range: 26-69 years) had chronically inflamed nasopharyngeal mucosal tissue. Histopathological assessment and grading were performed according to the 2003 edition of the American Joint Committee of Cancer (AJCC) and International Union Against Cancer (UICC) international tumor-node-metastasis (TNM) staging method. The study was approved by the Ethical Review Board of the First Affiliated Hospital of Guangxi Medical University.

Immunohistochemical staining. Paraffin-embedded samples were deparaffinized with xylene and rehydrated with graded ethanol. Antigen retrieval was carried out in EDTA buffer at $95^{\circ} \mathrm{C}$ for $10 \mathrm{~min}$. Endogenous peroxidase activity was blocked with fresh $3 \%$ hydrogen peroxide for $10 \mathrm{~min}$ at room temperature. After phosphate-buffered saline rinse, tissues were blocked for 10 min with normal serum to block nonspecific binding, and were then incubated overnight at $4^{\circ} \mathrm{C}$ with a 1:500 dilution of rabbit polyclonal anti-WWOX antibody (Abcam Company, Abcam, Cambridge, UK). Secondary antibodies were applied for $20 \mathrm{~min}$. Tissues were labeled for $60 \mathrm{~min}$ with two drops of avidin and two drops of biotinylated enzyme. DAKO liquid 3, 30-diaminobenzidine tetrahydrochloride (Maixin Biotechnology Corporation, Fuzhou, China) was applied for $1 \mathrm{~min}$ and observed by microscopy. Tissues were counterstained for 45-60 s with Mayer's hematoxylin, dehydrated with ethanol and xylene, and a cover slip was applied. Human skin tissue was used as the positive control according to the protocol. The same concentrations of non-immune rabbit serum were used as negative controls.

Immunohistochemical staining was evaluated and scored for WWOX protein in tumor tissue and inflammation tissue by two pathologists who were blinded to the clinical information. The intensity of staining was graded as follows: none (score: 0 ); weak $(+$, score: 1$)$; moderate $(++$, score: 2$)$; and strong $(+++$, score: 3 ). The extent of staining was evaluated as the percentage of positive cells per 1000 or more cells (at least 100 cells in 10 high-power fields) in each evaluated compartment, and was graded into six classes as follows: negative (score: 0 ); $<10 \%$ (score: 1 ); $11 \%-25 \%$ (score: 2 ); $26 \%-50 \%$ (score: 3 ); $51 \%-75 \%$ (score: 4 ); and $>75 \%$ (score: 5 ). A final score was calculated by multiplying intensity and extent scores for every compartment, and we distinguished four classes: one with positive ( $>$ a score of 3 ) and one with negative ( $<$ a score of 3 ) expression. The adjacent normal muscular and skeletal tissues were scored 10-15 and were considered as normal expression of WWOX protein.

Reverse transcriptase-polymerase chain reaction (RTPCR). RNA was isolated by Trizol (Takara Corporation, Tokyo, Japan) according to the protocol supplied by the manufacturer. The WWOX cDNA sequence was searched from Gen bank from NCBI. The $\beta$-actin gene was selected as the internal reference gene. The total amount of RNA was quantitated and the amount in the sample was calculated. Reverse transcription and PCR amplification were carried out according to the instructions as follows. Cycle conditions were one cycle of $95^{\circ} \mathrm{C}$ for $5 \mathrm{~min}, 33$ cycles of $94^{\circ} \mathrm{C}$ for $60 \mathrm{~s}, 64^{\circ} \mathrm{C}$ for $60 \mathrm{~s}$, and $72^{\circ} \mathrm{C}$ for $90 \mathrm{~s}$. Gene sequences were as follows: WWOX, sense 5'-GAGTTCCTGAGCGAGTGGAC-3' and antisense 5'-CCCCAGGAATTCCCTGCTT-3' (amplified product was $1490 \mathrm{bp}$ ); and $\beta$-actin, upstream 5'-AACAAGATGAGATTGGCA-3' and downstream 5'AGTGGGGTGGCTTTTAGGAT-3' (amplified product was $251 \mathrm{bp}$ ). The PCR product was identified with $1.5 \%$ agarose gel electrophoresis. The photos of PCR products were taken by automatic image analyzer under UV light. A corresponding length of the amplified bands would appear if the sample had gene expression. Similarly, thinner or lighter bands would appear if the sample had reduction in gene expression. Lastly, no specific amplification bands would appear if the sample had no gene expression. All the amplified bands of the corresponding PCR products would be quantitatively analyzed to get the relative expression quantity of target gene by Gel-pro Analyzer 4.5 software. Considering the stable mRNA expression of $\beta$-actin in various tissues, the relative expression of target gene would be calculated by the ratio of the optical density between target gene and $\beta$-actin.

Methylation-specific PCR (MSP). Genomic DNA was treated with sodium bisulfite with the EZ DNA Methylation-GOLD kit (Zymo Research Corp, Orange, USA) according to the manufacturer's instructions. WWOX methylation levels were detected by a semi-nested PCR. The primers for the first methylated sequence of WWOX were (F) 5'-AGGATTGGTTAGAATAACGC3' and (R) 5'-AAAATACCTAAAAAATCGCG-3', and those for the second methylated sequence of WWOX were (F) 5'-GTTCGAAATTGGATGCGTAC-3' and (R) 5'-CCTACGATCGAAAACGACGCGAACG-3'. Primers for the first un-methylated sequences were $(F)$ 5'-GTTTTG- TAGTTTTTGGAGTTAGTGTTGTGT-3' and (R) 5'-AAAAATACCTAAAAAATCACACT-3', and those for the second un-methylated sequences were $(F)$ 5' -TGGTTTGAAATTGGATGTGTAT-3' and (R) 5' CCTACGATCGAAAACGACGCGAACG -3'. For the first PCR amplification, cycle conditions were one cycle of $95^{\circ} \mathrm{C}$ for $5 \mathrm{~min}, 35 \mathrm{cycles}$ of $95^{\circ} \mathrm{C}$ for $45 \mathrm{~s}, 48^{\circ} \mathrm{C}$ for $45 \mathrm{~s}$, and $72^{\circ} \mathrm{C}$ for $45 \mathrm{~s}$. For the second PCR amplification, cycle conditions were one cycle of $95^{\circ} \mathrm{C}$ for $5 \mathrm{~min}, 35$ cycles of $95^{\circ} \mathrm{C}$ for 50 $\mathrm{s}, 48^{\circ} \mathrm{C}$ for $45 \mathrm{~s}$, and $72^{\circ} \mathrm{C}$ for $45 \mathrm{~s}$. The PCR product was 

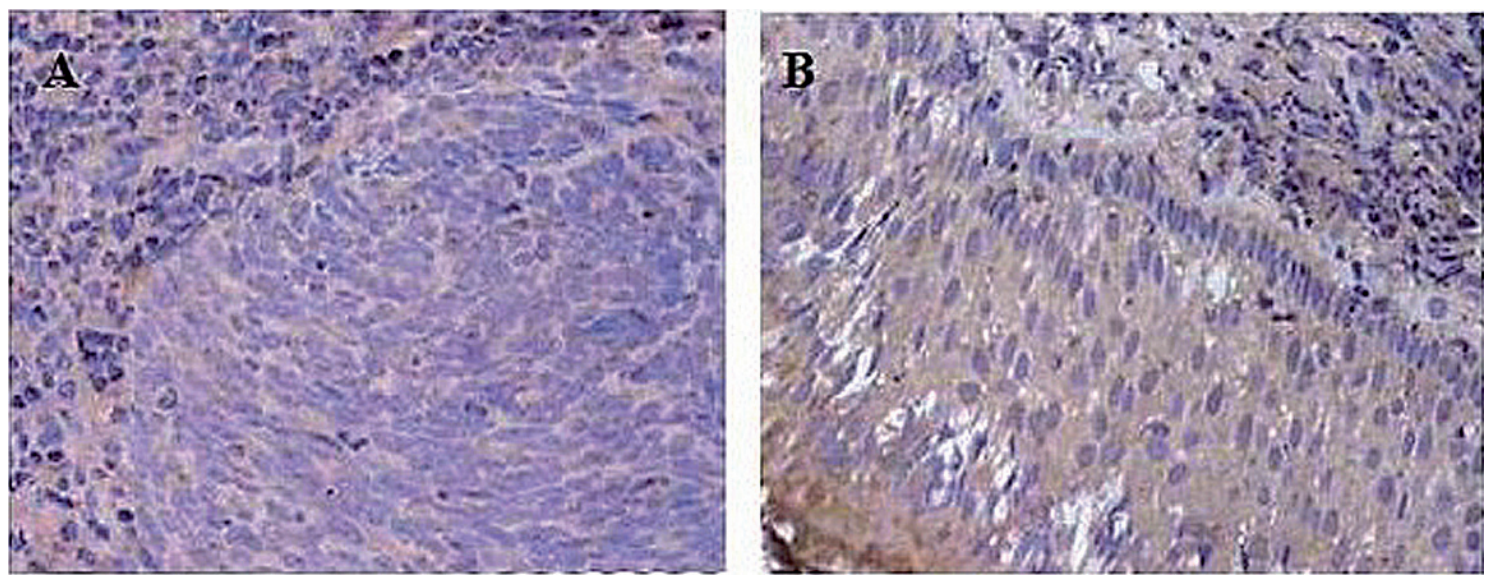

Figure 1. Representative photographs of immunohistochemical study of WWOX protein expression in NPC tissue specimens and chronically inflamed nasopharyngeal mucosal tissues. A): Representative photograph showing negative expression of WWOX protein in NPC tissue (400 $\times$ ). B): Representative photograph showing positive expression of WWOX protein in chronically inflamed nasopharyngeal mucosal tissue (400×).

identified with $1.5 \%$ agarose gel electrophoresis. Cases were defined as methylated when a PCR product was present with the appropriate primer pair.

LOH analysis. Allelic losses were analyzed by PCR amplification with three sets of primers for the micro satellites D16S518 (intron 1 of the WWOX gene), D16S3096, and D16S504 (intron 8). The primer sequences were obtained from the Genome database. PCR cycling programs included one cycle with $95^{\circ} \mathrm{C}$ for 10 min followed by 35 cycles consisting of $94^{\circ} \mathrm{C}$ for $30 \mathrm{~s}, 56^{\circ} \mathrm{C}$ (for D16S3096 and D16S504) or $55^{\circ} \mathrm{C}$ (for D16S518) for $30 \mathrm{~s}$, and $72^{\circ} \mathrm{C}$ for $60 \mathrm{~s}$. After amplification, $5 \mu \mathrm{l}$ of PCR product was mixed with $5 \mu$ l of loading dye ( $95 \%$ formamide, $20 \mathrm{mmol} / \mathrm{L}$ EDTA, $0.05 \%$ bromophenol blue, and $0.05 \%$ xylene cyanol), heated at $90^{\circ} \mathrm{C}$ for $3 \mathrm{~min}$, and then chilled on ice, and applied onto an $8 \%$ polyacrylamide gel with $5 \%$ glycerol. Last was carried out silver staining. $\mathrm{LOH}$ was scored if one of the heterozygous alleles showed at least $50 \%$ reduced intensity in tumor DNA compared with the corresponding normal DNA.

Statistical analysis. All statistical calculations were carried out using SPSS 13.0 statistical software (SPSS Corporation, Chicago, USA). The relationship between the transcription level of the WWOX gene and clinicopathological features was analyzed by the chi-square test. Spearman's (nonparametric) correlation was used to correlate WWOX expression with transcription levels of the WWOX gene, promoter methylation status, and the level of WWOX loss of heterozygosity. $P<0.05$ was considered statistically significant.

\section{Results}

Frequent loss of WWOX protein expression in NPC. To evaluate whether WWOX protein expression is altered in NPC, we performed immunohistochemical staining of WWOX expression. WWOX protein was significantly lower $(26 / 65[40 \%])$ in NPC tissue samples than in chronically inflamed nasopharyngeal mucosal tissue samples (30/43 [70\%], $P=0.002$, Figure 1 ).

Aberrant WWOX gene transcripts in NPC. Thirty-one of 65 patients (48\%) showed altered or absent expression of WWOX gene transcription in NPC tissue. All of the patients with chronically inflamed nasopharyngeal mucosal tissue had normal-sized transcripts without aberrant transcripts. There was a significant difference in the expression of WWOX gene between the two groups $(\mathrm{P}<0.001$, Figure 2$)$. Expression of WWOX mRNA in NPC tissue and chronically inflamed nasopharyngeal mucosal tissue has been shown in Table 1 . These results suggest that low expression of WWOX may be associated with the development of NPC.

We then determined the correlations between WWOX mRNA expression and clinicopathological variables. WWOX mRNA expression was not associated with clinical characteristics, including sex, age, and histological subtype. However, low expression of WWOX in NPC was related to TNM stage (Table 2).

Methylation of the WWOX gene promoter in NPC. We found that the WWOX promoter was methylated in $56.9 \%$

Table 1. Expression of WWOX mRNA in NPC tissue and chronically inflamed nasopharyngeal mucosal tissue by relative expression

\begin{tabular}{llll}
\hline Comparison & $\mathrm{N}$ & $\overline{\mathrm{x}} \pm \mathrm{S}$ & $\mathrm{P}$ \\
\hline NPC tissue & 61 & $0.69 \pm 0.34$ & -2.01 \\
chronically inflamed nasopharyngeal mucosal tissue & 20 & $0.89 \pm 0.49$ & \\
\hline
\end{tabular}




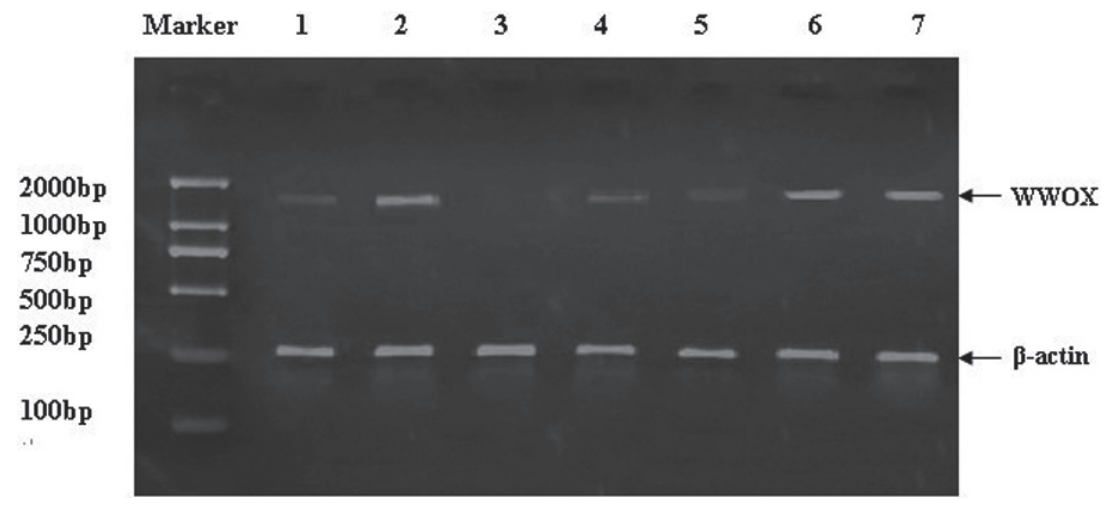

Figure 2. Expression of WWOX mRNA in NPC tissue and chronically inflamed nasopharyngeal mucosal tissue. M: DNA marker; 1-5: NPC tissues; 6-7: chronic inflammation tissues of the nasopharyngeal mucosa.

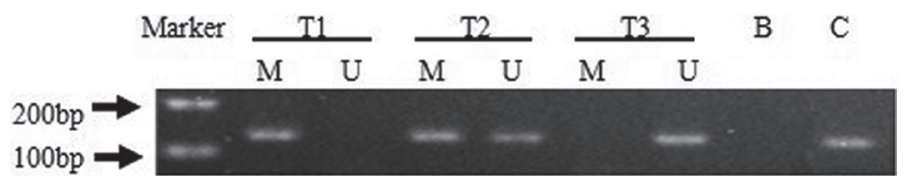

Figure 3. Methylation of the WWOX gene in NPC tissue. The methylation status of the WWOX gene promoter was determined by MSP analysis. T1 and T2 were methylated. M: methylated; U: un-methylated; B: blank; C: control; T1, T2, and T3: NPC tissues.

(37/65) of NPC tissue samples, while all of the chronically inflamed nasopharyngeal mucosal tissue samples were unmethylated (Figure 3).

LOH of the WWOX gene in NPC. We studied LOH using three micro satellite markers within the WWOX gene. The three micro satellites are located adjacent to the end of the WWOX gene, in intron 8 . We observed a relatively high percentage of $\mathrm{LOH}$ in NPC tissue samples. $\mathrm{LOH}$ was significantly higher in NPC tissue samples (29/65) than in chronically inflamed nasopharyngeal mucosal tissue samples $(2 / 43, P=0.001$, Figure 4).

Relationships among WWOX mRNA expression, promoter methylation, and LOH in NPC. A total 31 of 65 NPC tissue samples demonstrated loss of WWOX expression. WWOX gene promoter methylation was detected in 27 of 31 (87\%) WWOX protein negative tissues, whereas it was detected

Table 2. Relationship between WWOX mRNA deletion in 65 NPC tissue samples and clinicopathological characteristics

\begin{tabular}{|c|c|c|c|c|}
\hline Variables & & deletion $\%$ & $\chi^{2}$ & $P$ values \\
\hline \multirow{3}{*}{ Age at diagnosis } & $<40$ & $50.0(8 / 16)$ & \multirow{3}{*}{0.046} & \multirow{3}{*}{0.977} \\
\hline & $40 \sim 50$ & $47.0(16 / 34)$ & & \\
\hline & $>50$ & $46.7(7 / 15)$ & & \\
\hline \multirow{2}{*}{ Sex } & male & $48.1(26 / 54)$ & \multirow{2}{*}{0.027} & \multirow{2}{*}{0.870} \\
\hline & female & $45.5(5 / 11)$ & & \\
\hline \multirow{3}{*}{ histological subtype } & poorly differentiated squamous-cell carcinoma & $48.0(24 / 50)$ & \multirow{3}{*}{0.019} & \multirow{3}{*}{0.991} \\
\hline & Squamous cell carcinoma III & $50.0(1 / 2)$ & & \\
\hline & Non cornifying carcinoma & $46.2(6 / 13)$ & & \\
\hline \multirow{2}{*}{ TNM stage } & $\mathrm{I} \sim \mathrm{II}$ & $25.0(5 / 20)$ & \multirow{2}{*}{5.963} & \multirow{2}{*}{0.015} \\
\hline & III IV & $57.8(26 / 45)$ & & \\
\hline \multirow{2}{*}{ Tumor stage } & $\mathrm{T} 1 \sim \mathrm{T} 2$ & $34.5(10 / 29)$ & \multirow{2}{*}{3.662} & \multirow{2}{*}{0.056} \\
\hline & $\mathrm{T} 3 \sim \mathrm{T} 4$ & $58.3(21 / 36)$ & & \\
\hline \multirow{2}{*}{ Lymph node status } & No & $25.0(3 / 12)$ & \multirow{2}{*}{3.038} & \multirow{2}{*}{0.081} \\
\hline & $\mathrm{N} 1 \sim \mathrm{N} 3$ & $52.8(28 / 53)$ & & \\
\hline \multirow{2}{*}{ Metastasis } & M0 & $48.4(30 / 62)$ & \multirow{2}{*}{0.260} & \multirow{2}{*}{0.610} \\
\hline & M1 & $33.3(1 / 3)$ & & \\
\hline
\end{tabular}




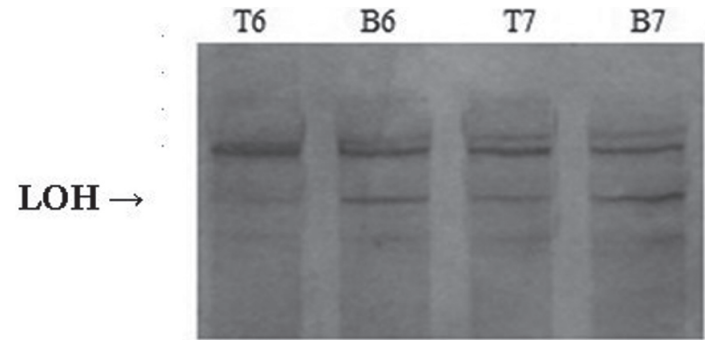

Figure 4. LOH of WWOX in NPC tissue. The band of D16S3096 is missing in the NPC tissue T6. T6 and T7: NPC tissues; B6 and B7: NPC blood specimens.

in 10 of $37(27 \%)$ WWOX protein positive tissues. Further analyses revealed that the methylation state of the distal promoter region had a notable effect on WWOX expression ( $r s=-0.582, P=0.001$, Table 3 ). However, there was no correlation between $\mathrm{LOH}$ and a reduction in WWOX expression (rs=-0.196, $P=0.117$, Table 4).

\section{Discussion}

The WWOX gene, encompassing FRA16D, is the second most actively common fragile site in the human genome. This gene region is prone to breakage with an increased risk for carcinogen-induced damage, and has been extensively reported as a common abnormality in various cancers and cancer-derived cell lines [19]. Accumulating evidence has shown that WWOX is a potential tumor suppressor. The WWOX protein interacts with $\mathrm{p} 53, \mathrm{p} 73, \mathrm{AP}-2 \mathrm{k}, \mathrm{YAP}, \mathrm{erbB} 4$, truncated c-met, and others by the WW domain in the regulation of cell growth and apoptosis [20-26]. The loss of WWOX has been observed in a variety of cancer cell lines and human cancers, including breast, ovarian, esophageal, lung, pancreatic, and

Table 3. Correlation between WWOX mRNA expression and promoter methylation in NPC

\begin{tabular}{|c|c|c|c|}
\hline \multirow[t]{2}{*}{ WWOX m RNA } & \multicolumn{2}{|c|}{ Methylation } & \multirow[t]{2}{*}{ Total } \\
\hline & + & - & \\
\hline+ & 10 & 24 & 34 \\
\hline - & 27 & 4 & 31 \\
\hline Total & 37 & 28 & 65 \\
\hline
\end{tabular}

Correlation value: $\mathrm{rs}=-0.582, P=0.001$

Table 4. Correlation between WWOX mRNA expression and LOH in NPC

\begin{tabular}{lccc}
\hline \multirow{2}{*}{ WWOX m RNA } & \multicolumn{2}{c}{ LOH } & \multirow{2}{*}{ Total } \\
\cline { 2 - 3 } & + & - & \\
\hline+ & 12 & 22 & 34 \\
- & 17 & 14 & 31 \\
Total & 29 & 36 & 65 \\
\hline
\end{tabular}

Correlation value: $r s=-0.196, P=0.117$ gastric carcinomas, and is associated with the development and progression of malignant tumors [5-11]. However, Watanabe et al. suggested that WWOX protein levels are not decreased, but are elevated instead in gastric and breast carcinoma, challenging the notion of WWOX as a classical tumor suppressor [27]. Therefore, it is controversial whether the WWOX gene is a tumor suppressor gene. There are no reports on the WWOX gene and protein in NPC. The present study was designed to determine expression of WWOX in NPC and gain insight into the role of the WWOX gene in the pathogenesis of NPC.

In our study, we showed a loss of WWOX protein expression in 26 of 65 tissue samples (40\%) from NPC patients. RT-PCR showed a loss of transcripts or aberrant transcripts in 31 of 65 (48\%) tissue samples from NPC patients. Therefore, alteration of WWOX gene expression is common in NPC. Our result is consistent with previous reports showing that low expression of WWOX might play an important role in the occurrence and development of malignant tumors. We also found that low levels of WWOX expression were associated with TNM stage in NPC. Other clinical characteristics, including age, sex, and histological subtype, did not show any significant association with the expression of WWOX. Therefore, abnormal expression of WWOX may be an early molecular phenomenon of NPC.

Recent previous studies have suggested that the loss of gene expression is due, at least in part, to epigenetic alterations, such as DNA methylation at the CpG sites within the promoter region $[13,28]$. DNA methylation at $\mathrm{CpG}$ dinucleotides in promoter regions is frequently associated with transcriptional silencing of tumor suppressor genes in cancer cells [29]. In the current study, we investigated the promoter methylation status of WWOX in NPC. Methylation at the WWOX promoter was frequently detected, and low expression of the WWOX gene had a significant correlation with WWOX promoter methylation. These results suggested that WWOX methylation and subsequent loss of expression occurred in the early stage of carcinogenesis and played an important role in cancer development in NPC. Additionally, we found that LOH of WWOX was frequent in NPC. These results are consistent with other previous reports that showed LOH in the WWOX gene in a number of cell lines and primary tumors, including the breast, prostate, lung, pancreas, and others [30-33]. In our study, WWOX expression and $\mathrm{LOH}$ were not correlated. We speculate that in NPC, LOH of the WWOX gene may be an independent event.

The development of NPC involves multiple steps and is mediated by many genes. Although the current study found that alteration of the WWOX gene may be related to development of NPC, the genetic regulation mechanisms are still unclear. The WWOX gene may interact with p53, p73, erbB4, bcl-2, and other transcription factors taking part in the generation, development and metastasis of the tumor. Recent research suggests that reactivation of WWOX by DNA methylation inhibitors restores the sensitivity of cancer cells to apoptosisinducing agents. Therefore, further study is necessary to clarify 
the mechanism. Through reversal of epigenetic alteration of the WWOX gene, enhancement of WWOX levels could provide a promising strategy for cancer therapy.

In conclusion, this is the first report to demonstrate that inactivation of the WWOX gene is a common event in NPC. Additionally, genetic changes of the WWOX gene, such as promoter methylation and $\mathrm{LOH}$, might be involved in the pathogenesis of NPC. We conclude that the gene silencing of WWOX is related to methylation of its promoter. These data suggest that WWOX is a potential biomarker for NPC patients.

Acknowledgements: This research was supported by grants from the National Natural Science Foundation of Guangxi (No. 2010GXNSFA013184).

\section{References}

[1] OLUWADARA O, BARKHORDARIAN A, GIACOMELLI L, BRANT X, CHIAPPELLI F. Immune surveillance of nasopharyngeal carcinoma (NpC). Bioinformation 2011; 7: 271-275. http://dx.doi.org/10.6026/97320630007271

[2] YU MC, YUAN JM. Epidemiology of nasopharyngeal carcinoma. Semin Cancer Biol 2002; 12: 421-429. http://dx.doi. org/10.1016/S1044579X02000858

[3] CHUA DT, MA J, SHAM JS, MAI HQ, CHOY DT, et al. Longterm survival after cisplatin-based induction chemotherapy and radiotherapy for nasopharyngeal carcinoma: a pooled data analysis of two phase III trials. J Clin Oncol 2005; 23:1118-1124. http://dx.doi.org/10.1200/JCO.2005.12.081

[4] BEDNAREK AK, LAFLIN KJ, DANIEL RL, LIAO Q, HAWKINS KA, et al. WWOX, a novel WW domain-containing protein mapping to human chromosome 16q23.3-24.1, a region frequently affected in breast cancer. Cancer Res 2000; 60: 2140-2145.

[5] PLUCIENNIK E, KUSINSKA R., POTEMSKI P, KUBIAK R, KORDEK R, et al. WWOX--the FRA16D cancer gene: expression correlation with breast cancer progression and prognosis. Eur J Surg Oncol 2006; 32: 153-157. http://dx.doi. org/10.1016/j.ejso.2005.11.002

[6] DONATI V, FONTANINI G, DELL'OMODARME M, PRATI MC, NUTI S, et al. WWOX expression in different histologic types and subtypes of non-small cell lung cancer. Clin Cancer Res 2007; 13: 884-891. http://dx.doi.org/10.1158/1078-0432. CCR-06-2016

[7] RAMOS D, ABBA M, LÓPEZ-GUERRERO JA, RUBIO J, SOLSONA E, et al. Low levels of WWOX protein immunoexpression correlate with tumour grade and a less favourable outcome in patients with urinary bladder tumours. Histopathology 2008; 52: 831-839. http://dx.doi.org/10.1111/ j.1365-2559.2008.03033.x

[8] AQEILAN RI, KUROKI T, PEKARSKY Y, ALBAGHA O, TRAPASSO F, et al. Loss of WWOX expression in gastric carcinoma. Clin Cancer Res 2004; 10: 3053-3058. http://dx.doi. org/10.1158/1078-0432.CCR-03-0594

[9] AARHUS M, BRULAND O, BREDHOLT G, LYBAEK H, HUSEBYE ES, et al. Microarray analysis reveals down-regula- tion of the tumour suppressor gene WWOX and up-regulation of the oncogene TYMS in intracranial sporadic meningiomas. J Neurooncol 2008; 88: 251-259. http://dx.doi.org/10.1007/ s11060-008-9569-6

[10] LEWANDOWSKA U,ZELAZOWSKI M, SETA K, BYCZEWSKA M, PLUCIENNIKE, et al. WWOX, the tumour suppressor gene affected in multiple cancers. J Physiol Pharmacol. 2009; 60 Suppl 1: 47-56.

[11] GOURLEY C, PAIGE AJ, TAYLOR KJ, WARD C, KUSKE B, et al: WWOX gene expression abolishes ovarian cancer tumorigenicity in vivo and decreases attachment to fibronectin via integrin alpha3. Cancer Res 2009; 69: 4835-4842. http:// dx.doi.org/10.1158/0008-5472.CAN-08-2974

[12] ILIOPOULOS D, GULER G, HAN SY, DRUCK T, OTTEY $\mathrm{M}$, et al. Roles of FHIT and WWOX fragile genes in cancer. Cancer Lett 2006; 232: 27-36. http://dx.doi.org/10.1016/ j.canlet.2005.06.048

[13] ILIOPOUlOS D, GULER G, HAN SY, JOHNSTON D, DRUCK T, et al. Fragile genes as biomarkers: epigenetic control of WWOX and FHIT in lung, breast and bladder cancer. Oncogene 2005; 24: 1625-1633. http://dx.doi.org/10.1038/ s..onc. 1208398

[14] KUROKI T, TRAPASSO F, SHIRAISHI T, ALDER H, MIMORI K, et al: Genetic alterations of the tumor suppressor gene WWOX in esophageal squamous cell carcinoma. Cancer Res 2002; 62: 2258-2260.

[15] YENDAMURI S, KUROKI T, TRAPASSO F, HENRY AC, DUMON KR, et al: WW domain containing oxidoreductase gene expression is altered in non-small cell lung cancer. Cancer Res 2003; 63: 878-881.

[16] WANG M, GU J, WANG Y, GONG B. Loss of WWOX expression in human extrahepatic cholangiocarcinoma. J. Cancer Res Clin Oncol 2009; 135: 39-44. http://dx.doi.org/10.1007/ s00432-008-0449-4

[17] QIN HR, ILIOPOULOS D, SEMBA S. A role for the WWOX gene in prostate cancer.Cancer Res 2006; 66: 6477-6481. http://dx.doi.org/10.1158/0008-5472.CAN-06-0956

[18] WATANABE A, HIPPO Y, TANIGUCHI H, et al: An opposing view on WWOX protein functions as a tumor suppressor. Cancer Res. 2003; 63(24): 8629-8633.

[19] O'KEEFE LV, RICHARDS RI. Common chromosomal fragile sites and cancer: focus on FRA16D.Cancer Lett 2006; 232: 37-47. http://dx.doi.org/10.1016/j.canlet.2005.07.041

[20] YANG J, ZHANG W. WWOX tumor suppressor gene. Histol Histopathol 2008; 23: 877-882.

[21] AQEILAN RI, PEKARSKY Y, HERRERO JJ, PALAMARCHUK A, LETOFSKY J, et al. Functional association between Wwox tumor suppressor protein and p73, a p53 homolog. Proc Natl Acad Sci USA 2004; 101: 4401-4406. http://dx.doi. org/10.1073/pnas.0400805101

[22] AQEILAN RI, PALAMARCHUK A, WEIGEL RJ, HERRERO JJ, PEKARSKY Y, et al. Physical and functional interactions between the Wwox tumor suppressor protein and the AP2 gamma transcription factor.Cancer Res 2004; 64: 8256-8261. http://dx.doi.org/10.1158/0008-5472.CAN-04-2055

[23] GULER G., ILIOPOULOS D, GULER N, HIMMETOGLU C., HAYRAN M, et al. WWOX and Ap2gamma expression levels 
predict tamoxifen response.Clin Cancer Res 2007; 13: 61156121. http://dx.doi.org/10.1158/1078-0432.CCR-07-1282

[24] MAATTA JA, SUNDVALL M, JUNTTILA TT, PERI L, LAINE VJ, et al. Proteolytic cleavage and phosphorylation of a tumor-associated ErbB4 isoform promote ligand-independent survival and cancer cell growth.Mol Biol Cell 2006; 17: 67-79. http://dx.doi.org/10.1091/mbc.E05-05-0402

[25] JUNTTILA TT, SUNDVALL M, LUNDIN M, LUNDIN J, TANNER M, et al. Cleavable ErbB4 isoform in estrogen receptor-regulated growth of breast cancer cells. Cancer Res 2005; 65: 1384-1393. http://dx.doi.org/10.1158/0008-5472. CAN-04-3150

[26] AQEILAN RI, DONATI V, PALAMARCHUK A, TRAPASSO F, KAOU M, et al. WW domain-containing proteins, WWOX and YAP, compete for interaction with ErbB-4 and modulate its transcriptional function. Cancer Res 2005; 65: 6764-6772. http://dx.doi.org/10.1158/0008-5472.CAN-05-1150

[27] WATANABE A, HIPPO Y, TANIGUCHI H, IWANARI H, YASHIRO $\mathrm{M}$, et a1. An opposing view on WWOX protein function as a tumor suppressor. Cancer Res 2003; 63: 86298633.

[28] NAKAYAMA S, SEMBA S, MAEDA N, MATSUSHITA M, KURODA Y, et a1. Hypermethylation-mediated reduction of WWOX expression in intraductal papillary mucinous neoplasms of the pancreas.Br J Cancer 2009; 100: 1438-1443. http://dx.doi.org/10.1038/sj.bjc.6604986

[29] TAO Q, CHAN AT. Nasopharyngeal carcinoma: molecular pathogenesis and therapeutic developments.Expert Rev Mol Med 2007; 9: 1-24. http://dx.doi.org/10.1017/ S1462399407000312

[30] BEDNAREK AK, LAFLIN KJ, DANIEL RL, LIAO Q., HAWKINS KA, et a1. WWOX, a novel WW domain-containing protein mapping to human chromosome 16q23.3-24.1, a region frequently affected in breast cancer. Cancer Res 2000; 60: 2140-2145.

[31] KUROKI T, TRAPASSO F, SHIRAISHI T, ALDER H, MIMORI K, et al. Genetic alterations of the tumor suppressor gene WWOX in esophageal squamous cell carcinoma. Cancer Res 2002; 62: 2258-2260.

[32] KUROKI T, YENDAMURI S, TRAPASSO F, MATSUYAMA A, AQEILAN RI, et al. The tumor suppressor gene WWOX at FRA16D is involved in pancreatic carcinogenesis. Clin Cancer Res 2004; 10: 2459-2465. http://dx.doi.org/10.1158/10780432.CCR-03-0096

[33] PAIGE AJ, TAYLOR KJ, TAYLOR C, HILLIER SG, FARRINGTONS, et al. WWOX: a candidate tumor suppressor gene involved in multiple tumor types. Proc Natl Acad Sci USA 2001; 98: 11417-11422. http://dx.doi.org/10.1073/pnas.191175898 